\title{
QUALITATIVE ANALYSIS OF FOOD SPECTRUM OF FIVE SPECIES OF ANURAN TADPOLES FROM ARUNACHAL PRADESH, INDIA
}

\author{
Bikramjit Sinha, Paramita Chakravorty, Mohini Mohan Borah and Sabitry Bordoloi \\ Ecology Laboratory, Department of Zoology, Cotton College, Guwahati, Assam 781001, India.
}

\begin{abstract}
Anuran tadpoles were collected from amphibian habitats of Arunachal Pradesh during the breeding season from March to September. Taxonomic identification of the tadpoles was done with the help of existing literature (Sahu, 1981). Gut content analysis of five species of tadpoles was done to know the food consumed. Tadpoles between stage 30 to 38 (Gosner, 1960) were selected for the study. Bufo melanostictus, Amolops afghanus, Euphlyctis cyanophlyctis, Rana danieli and Rhacophorus maximus were studied. This is the first study on food habit of tadpoles in Arunachal Pradesh and will help in the study of habitat deterioration and floristic composition of amphibian habitats in future.
\end{abstract}

\section{Keywords}

Amphibians, anuran tadpoles, food spectrum, Arunachal Pradesh

\section{Introduction}

Knowledge of food and feeding behaviour of the tadpoles is very essential as early part of the life history of amphibia is dependent on the availability of the food items in the natural habitat. Degradation of aquatic habitat due to increasing anthropogenic stress is an universal phenomenon. Habitat loss is one of the important causes of the decline of amphibian fauna world over. During our exploration work in Arunachal Pradesh amphibian habitats were studied and an attempt has been made to know the food preference of these tadpole in the undisturbed habitat. Tadpoles were collected from these water bodies and gut content analysis was done in the laboratory. Study of food of tadpoles in northeastern India was earlier done by Sahu and Khare (1988) on Rana alticola tadpoles in Meghalaya. They observed that in the early part of life history, tadpoles are herbivorous which later changes to carnivorous in the post metamorphic stages.

Received 29 December 2000

Accepted 17 March 2001

\section{Methodology}

Tadpoles were collected from temporary and permanent water bodies of Arunachal Pradesh. They were collected with hand net and preserved in $10 \%$ formaldehyde solution soon after collection. Stage 30-38 (Gosner, 1960) tadpoles were selected for the study. Guts were removed, gut length recorded and $10 \mathrm{~mm}$ from the fore gut and $10 \mathrm{~mm}$ from the hind gut were taken for analysis. The content was washed in $1.0 \mathrm{ml}$ distilled water and placed in a sedgwick rafter. Food items were identified with the help of standard literature.

\section{Observation}

Five species of anuran tadpoles were selected for the study on the basis of their availability in most of the amphibian habitats in Arunachal Pradesh. The species are Bufo melanostictus, Rhacophorus maximus, Amolops afghanus, Rana danieli, and Euphlyctis cyanophlyctis. The study has shown that the major food item preferred was phytoplankton. Species of zooplankton recorded could be chance intake as they were found only in one or two cases. Food items found in the gut content of ten tadpoles, each selected from stage 30 to 38 (Gosner, 1960), are as follows.

Bufo melanostictus Schneider, 1799 (Common Asian Toad) Body length: $9.8-10.7 \mathrm{~mm}$

Gut length: $116-144 \mathrm{~mm}$.

Gut contents:

Phytoplankton: Myxophyceae - Oscillatoria sp, Anabaena sp. Chlorophyceae - Ulothrix sp., Natrium sp., Cosmerium sp., Closterium sp., Oedogonium sp., Penium sp., Microspora sp., Spirogyra sp., Zygnema sp.,

Diatoms - Synedra sp., Cymbella sp., Navicula sp., Pinnularia sp., Amphora sp., Nitzschia sp., Diatoma sp., Surirella sp., Tabellaria sp., Melosira sp.,

Zooplankton: Rotifera - Lecane sp., Monostyla sp., Lepadella sp.,

Rhacophorus maximus Günther, 1858 (Large Tree Frog)

Body length: $9.5-11.5 \mathrm{~mm}$

Gut length: $53-87.4 \mathrm{~mm}$ 
Gut contents:

Phytoplanktons: Cyanophyceae - Microcystis sp., Oscillatoria sp., Anabaena sp.

Chlorophyceae - Closterium sp., Oedogonium sp., Scenedesmus sp., Desmidium sp., Staurastrum sp., Cylindrocystis sp., Cosmerium sp., Euastrum sp., Hydrodictyon sp.

Diatoms - Pinnularia sp., Gyrosigma sp., Eunotia sp., Navicula sp., Nitzschia sp., Synedra sp., Amphora sp., Cymbella sp., Stauroneis sp., Tabellaria sp., Surirella sp.

Zooplankton: Copepoda - Cyclops sp.

Rotifera - Lepadella sp., Platyias sp.

Amolops afghanus (Günther, 1858) (Meghalaya Stream Frog) Body length: $9-13.00 \mathrm{~mm}$

Gut length: 46-76mm.

Gut contents:

Phytoplanktons: Cyanophyceae - Oscillatoria sp., Anabaena sp., Lyngbya sp.

Diatoms - Achnanthes sp., Cyclotella sp., Synedra sp., Navicula sp., Meridion sp., Nitzschia sp., Cymbella sp., Tabellaria sp., Diatoma sp., Cocconeis sp.

Chlorophyceae - Cosmerium sp., Oedogonium sp., Microspora sp.

Zooplankton: Rotifera - Philodina sp., Lecane sp.

\section{Euphlyctis cyanophlyctis (Schneider, 1799) (Indian Skipping} Frog)

Body length: 13.2-18.9mm.

Gut length: 124-308mm.

Gut contents:

Phytoplanktons: Diatoms - Cymbella sp., Synedra sp, Navicula sp, Gyrosigma sp., Pinnularia sp., Nitzschia sp., Surirella sp., Stauroneis sp., Diatoma sp.,

Myxophyceae - Anabaena sp., Oscillatoria sp., Merismopedia sp.

Cholorphyceae - Cosmerium sp., Spirogyra sp., Zygnema sp., Netrium sp., Euastrum sp., Ulothrix sp., Tribonema sp., Oedogonium sp., Scenedesmus sp.

Zooplankton: Rotifera - Lecane sp., Monostyla sp.

Copepoda - Cyclops sp., Cypris sp.,

\section{Rana danieli Pillai and Chanda, 1977 (Daniel's Frog)}

Body length: $13.5-19.5 \mathrm{~mm}$.

Gut length: 123-262mm.

Gut contents:

Phytoplanktons: Diatoms - Navicula sp., Diatoma sp., Synedra sp., Pinnularia sp., Surirella sp., Gyrosigma sp.

Chlorophyceae - Spirogyra sp., Closterium sp., Mesotaenium sp., Cosmerium sp., Penium sp., Euastrum sp., Oedogonium sp., Netrium sp., Chydorus sp., Mougeotia sp., Staurastrum sp., Cylindrocystis sp., Scenedesmus sp., Docidium sp., Pleurotaenium sp.

Cyanophyceae - Oscillatoria sp., Anabaena sp., Lyngbya sp., Merisenopedia sp.

\section{Discussion}

Analysis of food spectrum of tadpoles is important in view of the considerable attention amphibian species have received because of the proposed role of amphibians as indicators of ecosystem deterioration (Wake, 1991). The flora and fauna of the wet land can determine the amphibian species the ecosystem can support. Knowledge of the food of tadpoles of various species can be of use in rearing the species with medicinal values under laboratory conditions. Altig and Kelly (1974) studied indices of feeding in anuran tadpoles as indicated by gut characteristics. Earlier record of study on food habit of tadpoles in the north eastern region is that of Sahu and Khare (1988) who studied food and feeding habits of Rana alticola tadpoles in Shillong.

The present study on the five species of tadpoles give a qualitative account of the food on which these tadpoles depend. All the species prefer Diatoms and Chlorophyceae. In case of the Bufo melanostictus and Euphlyctis cyanophlyctis, Cyanophyceae was not recorded at all showing absence of cyanophyceae in these habitats. Similarly Myxophyceae was not recorded in case of $R$. danieli, A. afghanus and $R$. maximus. The gut content analysis of tadpoles gives a clear idea of the food items present in their habitat.

Detailed investigation will lead to many interesting findings regarding amphibian habitat in this biodiversity hotspot area of the world.

\section{Acknowledgement}

Authors express their gratitude to the G.B. Pant Institute of Himalayan Environment and Development, Kosi - Katarmal, Almora, Uttaranchal, India for financial assistance during the period of investigation.

\section{References}

Altig, R. and P.J. Kelly (1974). Indices of feeding in anuran tadpoles as indicated by gut characteristics. Herpetologica 30(2): 200-203.

Das, I and S.K. Dutta (1998). Checklist of the amphibians of India with English common names. Hamadryad 23(1): 63-68.

Gosner, K.L. (1960). A simplified table for staging Anuran embryos and larvae with notes on identification. Herpetologica 16: 183-190.

Sahu, A.K. (1981). Studies on the systematics and ecology of certain anuran tadpoles of North East India. Ph.D. Thesis: 166-171 (Unpublished).

Sahu, A.K. and M.K. Khare (1988). Food and feeding habits of Rana alticola Boulenger (Anura: Ranidae) during different stages of metamorphosis. Journal of Advanced Zoology 9(2): 97-104.

Wake, D.B. (1991). Declining amphibian populations. Science 253: 860 . 